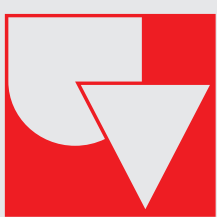

Universidad del Valle

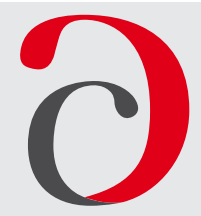

Cuadernos de Administración

\title{
A theoretical approach to neuroscience technologies' contributions to administration in the digital transformation context
}

\author{
Una aproximación teórica a las contribuciones de las tecnologías en neurociencias al \\ campo de la administración en un contexto de transformación digital
}

\section{${ }^{1}$ Alexander Varón SandovaliD}

Associate Professor, Administration, and Organizations Department, Faculty of Administration Sciences Universidad del Valle, Cali, Colombia. e-mail: alexander.varon@correounivalle.edu.co

\section{${ }^{2}$ Lizeth Carolina Zapata Castillo (D)}

Master's student in: Organizations Sciences, Administration, Faculty of Administration Sciences, Universidad del Valle, Cali, Colombia. e-mail: zapata.lizeth@correounivalle.edu.co

Review Article Submitted: $21 / 10 / 2020$

Reviewed: 26/03/2021

Accepted: 06/05/2021

Published: 21/06/2021

Thematic lines: Marketing,

Administration and Organizations

JEL classification: M10, M30

DOI: https://doi.org/10.25100/cdea.v37i69.10691

\begin{abstract}
This paper intends to make an approximation to the contributions of neuroscience technologies to administration in a digital transformation context, which will be done through a bibliographic search and document analysis based on a review of databases and the collection of those sources considered most relevant to the topic at hand concerning some of the most critical dimensions in this area, such as human resources, leadership, decision-making, and digital business ecosystems. Likewise, it seeks to make a theoretical reflection on the use of neurosciences as a management tool of relevance to organizations. Among the main findings is that applying neuroscience techniques and the traditional ones can improve critical processes within organizations.
\end{abstract}

Keywords: Neurosciences, Administration, Decision-making, Leadership, Human resources, Digital transformation.

\section{Resumen}

El presente artículo tiene como propósito principal establecer una aproximación sobre cuáles son los aportes de las tecnologías en neurociencias al campo de la administración dentro de un contexto de transformación digital,

1 Business Administration, Universidad Icesi, Colombia, Doctorate's student in Social and Legal Sciences Doctorate (business research line), Universidad Rey Juan Carlos, Spain, and Doctorate's student in Management Doctorate, Universidad EAN, Colombia.

2 Marketing Professional, Universidad Libre, Cali, Colombia. 
esto se hará a partir de una búsqueda bibliográfica y un análisis documental basándose en la revisión respectiva de bases de datos y la extracción de las fuentes que se consideraron más relevantes para el tema tratado, sobre algunas de las dimensiones más importantes de este ámbito, como por ejemplo lo son, los recursos humanos, el liderazgo, la toma de decisiones y los ecosistemas digitales de negocios. Así mismo, se busca hacer una reflexión teórica sobre el uso de las neurociencias como una herramienta importante de gestión en las organizaciones. Uno de los principales hallazgos radica en que la aplicación de técnicas traídas de las neurociencias en complemento con las tradicionales puede llegar a mejorar procesos importantes dentro de las organizaciones.

Palabras Clave: Neurociencias, Administración, Toma de decisiones, Liderazgo, Recursos humanos, Transformación digital.

\section{Introduction}

Knowledge of the brain, the thoughts on which decision-making is based, how we act or communicate are relevant factors that people and companies should know. Therefore, delving into the principles and developing the appropriate strategies is essential for proper employee and company development (Salas, 2013).

Studying the brain, introducing neuroscience in companies and among managers should be a common practice. Implementing cognitive techniques in organizations should be a core objective to facilitate achieving personal and company goals, encourage and strengthen innovation, and improve full communication. That will better and further cause people and teams to identify with the company (Mozaz, 2009).

In this vein, applied neurosciences are crucial for innovation in leadership, direction, and organization management (Braidot, 2008). Achieving the foregoing requires harnessing neuroscience tools such as the electroencephalogram (EEG), functional magnetic resonance imaging (FMRI), Eye tracking, Facial movement coding system (FACS), among others (Chávarro and Piña, 2017); (Álvarez, 2012); (Ekman and Oster, 1972).

Concerning the above and the relevance of neuroscience in administration, Braidot (2014) proposes Neuromanagement as the application of Neuroscience to the management and conduction of organizations. The author asserts that Neuromanagement focuses on:

- Neurological processes related to decision making.

- The development of individual and organizational intelligence (team intelligence).

- The planning and management of people (selection, training, group interaction, and leadership).

For Braidot (2014), the benefits of applying Neurosciences to administrative work are in short:

- Enhanced leadership skills development.

- Increased ability to make effective decisions.

- Decreased risk of wrong-choosing people.

- Enriched methods for creativity development.

- Research and new products and services creation gain new dimensions.

The unstopped search for the ability to manage labor relations beyond an economic benefit was the outcome of acknowledging the importance of group behavior, sense of belonging, identity, motivation, selfrealization, as well as the attendant organizational skills capable of improving resource and production efficiency, and business development (Bancayan and Dávila, 2018). Thus, neurosciences applied to administration and its different techniques become relevant for companies.

In order to fulfill the outlined objective and approximate the contributions of neurosciences to the organizational arena, a bibliographic search and a documentary analysis were carried out, referencing the sources deemed relevant.

In accordance with the above, this a fourpart document outlines as follows: The first section shows relevant neuroscience aspects applied to human resource management, the second one to leadership, and the third one to decision-making, supplemented by the technological context in terms of digital 
ecosystems and digital transformation. Lastly, there will be the conclusions drawn from the review.

\section{Neurosciences applied to human resource management}

The development of neurosciences as an interdisciplinary hub has been highlighted in terms of advancements in knowledge of the brain's functioning, delving into untilthen neglected aspects due to the lack of technology for addressing and harnessing such knowledge to develop practical applications that bring about positive results. Neurosciences have entered various fields, among which administration sciences stand out (Albano, Oviedo, Santero, Sassone, and Martín, 2016).

Applying neuroscience knowledge to administration sciences could improve people's empathic relationships in organizations and organizations' relationships with the environment (Tetaz, 2015).

Neurosciences are applied to different aspects of administration (Daparo, Sánchez, and Serrano, 2015). The goal is business progress, and success and the starting point is satisfied internal and external customers. There is no business success without a market appropriately satisfied, and the company's offer cannot be suitable if not by all-personnel dedication and commitment (Albano, Oviedo, Santero, Sassone, and Martín, 2016). To that end, it is necessary to create tools that satisfy the internal customer needs, which is achieved through motivation.

When it comes to motivation, there is no universality, and, therefore, each individual will become motivated differently. Neurosciences support the field of motivation, allowing us to understand and know precisely, through brain scans, individuals' motivational factors' true incidence. Different incentives might trigger the reward neurocircuit, even if unaware that such a reward is expected (Albano, Oviedo, Santero, Sassone, and Martín, 2019).
The areas involved in reward processing, which accordingly act on the motivational system(Grupo Braidot, s.f.) (Manes and Niro, 2015), are:

- Ventral striatum: reward prediction: the ventral pallid is triggered in the expectation of a financial reward.

- Nucleus accumbens: the anticipation of gain.

- Orbitofrontal cortex: gives valence (value to the stimulus) concerning response and the results. It provides feedback when rewards are different than expected.

- Amygdala: it is related to the intensity of the reward.

The evidence has proved that the neuroanatomical regions and their neuropsychological functions are relevant in managing human resources because work behaviors are due to those areas (Bancayan and Dávila, 2018).

It has also be shown how studying the prefrontal cortex enables the development of organizational skills. As a result, organizational competencies can afford motivation-enabling behavior, teamwork, and communication, which are later on reflected in the perceived organizational climate and interpersonal relationships (Bancayan and Dávila, 2018). Below are some techniques used in the human resource management processes such as personnel selection, induction, training, and workplace wellbeing.

One of the tools that neurosciences have afforded human resource management for personnel selection, specifically, is precisely for one of the most challenging processes for candidates to overcome: the interview. For use, the "Neuropsychology" or "Affective" applications are necessary, and the consultant must have a computer with a webcam. In this case, an integrated camera placed in front of the applicant has been used, and it records the emotions elicited during the interview, so the results produced by the software will be available to the interviewer later on, which will allow them to compare whether the responses that the applicant verbalized match the emotions that he or 
she experienced (Pocoví, 2013). Likewise, the Facial Movement Coding System (FACS) makes it possible to study universal expressions to express happiness, sadness, rage, surprise, fear, and disgust (Ekman and Oster, 1972). Because emotion is construed as the ability to communicate feelings and make known the moods that allow others to identify what the other is feeling (Jeanneret, Oña, Rego, Vaiman, and Pereno, 2015), in the case of human resources, it would be the consultant or psychologist who is conducting the interview.

Biofeedback(which harnessesskingalvanic response elements, electrocardiography, and others for machines like the polygraph, galvanometers, specific software, among others) is amply used in admission tests in many organizations worldwide (El Empleo, 2017; Salazar, 2019)

Another neuroscience-based technique is job shadowing. Job shadowing is the technique where a worker spends a certain amount of time directly observing a worker who performs the same tasks for which he o she is undergoing training. Hence the term job shadowing (professional observation), for the worker undergoing training becomes a "shadow" to the person who performs the tasks, observing in detail the tasks to be executed and taking note of those details that make up the proper performance of the needs of the job in question (Reyes and Narváez, 2018). This technique is used in induction and training processes for new employees.

The technique is grounded in the functioning of mirror neurons, whose core mission is to mirror the activity being observed. In this way, the new would-be employee activates these neurons in their brain by contemplating the execution of specific tasks, causing their brain to simultaneously represent the same guidelines for carrying out the task (Fernández V., 2015).

Another human resource management process is the reward system (emotional salary, job flexibility, support, and professional growth, among others), which has an explanation in the neurosciences. The scientist Wolfram Schultz affirms that the stimuli that excite dopaminergic neurons (the reward circuit) can drive learning and motivation (Schultz, 2015), wherefore its application would impact the organization's collaborators.

In short, these tools help optimize time, money, and methodology and human resources processes such as personnel selection, induction, and development, turning them into technology-based processes capable of improved results and lowered turnover rates (Pocoví, 2013). There is plenty of evidence of their use in business on different websites about organizational matters, among which we can mention the company blogs such as Brain Investigations (Brain Vestigations, 2018), Revista Digital Inesem (Fernández V., 2015), SesameTime (Sesametime, undated), Employment Orientation (OPEM, undated), International School of Business Neuroscience (Esco Universitas, undated), among others. Work on the issue is also done in training courses on planning and human resources integration (Barcena, Cruz, Dávila, León, Montiel, and Pichardo, 2019).

\section{Neurosciences applied to leadership}

Over the years, the sciences studying the brain have developed a new specialty known as neuroleadership. This new approach has managed to position itself in different fields of labor under the support of various neuroscience discoveries that brought remarkable improvements in the growth of organizations, thereby becoming a fundamental management tool. In addition, Neuroleadership has managed to conflate with traditional forms of leadership, thus becoming scientific and rigorous in nature (Ghadiri, Habermacher, and Peters, 2012).

Neuroleadership is the application of neurosciences and what can be learned from them regarding how people lead and manage teams and the human factor and general business issues. Nowadays, thanks to neurosciences, we know how attention, motivation, emotion, cognition work. It is a series of factors that teach us how to lead people better to reach their goals and improve an organization's staff effectiveness and efficiency (Poelmans, 2014). 
The term neuroleadership was mentioned for the first time between 2008 and 2009 by David Rock, who has made a great effort to disseminate it (Poelmans, 2014). However, Otalora (2017) asserts the term was first coined in 2012, not in 2009, during a conference at the Universidad de la Rioja where the matter of how leaders' brains work and how they become "quiet leadership" that "leads over time" was being dealt with.

According to Braidot (2013), among the factors that have driven this new approach's growth is the development of equipment that allows observing brain reactions in realtime. For example, the author claims that the best equipment is brain scans, functional magnetic resonance imaging (FMRI) as these allow seeing which areas of the leader's brain are trigger when undergoing a motivational process with their group and thereby to what extent do emotions favor or hinder their performance.

Some of the valuable discoveries harnessed in neuroleadership, according to Vallejo, Abarca, Uquillas, and Ramirez (2017), are:

- Neuroplasticity: the brain's ability to reform, reshape, and reorganize.

- Neurolearning: teaching knowing what your mental potential is and how the brain learns.

- Learning by association: association is the way people learn.

Neurosciences cover different disciplines such as neurology, neurobiology, neurochemistry, neurophysiology, and cognitive neuroscience. Nevertheless, cognitive neuroscience may be most helpful in studying these phenomena (Waldman, Balthazard, and Peterson, 2011) by understanding cognitive and social interaction (Caballero and Lis, 2016). Some contributions of neuroscience to leadership include the following:

- Emotional regulation: a leader must know how to manage his or her emotions, especially negative ones, because these cannot be transmitted onto the team in order not to jeopardize performance (Boyatzis, Passarelli, Koening, Mathew, Mathew, Stoller and Philips, 2012). The authors Ochsner and Lieberman (2001) propose five ways how leaders can regulate their emotions: the first is by selecting strategies as a predictive and anticipatory mechanism, which enables them to face altered emotional states; the second is to face the situation intending to change it; the third is to focus on a different aspect of the situation to elicit a positive reaction; the fourth is to reinterpret the situation in order to lessen the emotional response to it, and the fifth is revaluation.

- Influence: leaders must be able to influence others positively. The ability to influence is subject to the ability to process information. Perform that process requires engaging the active memory. Its methods for processing are visual and auditory. The latter is triggered through melodies or messages that enter through the ear and engages the auditory cortex. The former, through visual material, triggers the visual cortex that is better able to process information due to more connections to the brain. The possibility of making other people visualize what is said is a mechanism to influence them, also known as "storytelling," i.e., the ability to tell memorable stories that positively influence others (Fredericksen, 2017).

- Generating change: making a change in an organization is not an easy task because change is perceived as a threat, and the limbic level of the brain is prepared to face threats. It assesses the situation instantaneously and sends the prefrontal cortex red flags that are manifest themselves in people's thoughts and behaviors. Cognitive neurosciences can help counteract those negative behaviors through effective communication that clearly shows the objectives of the change and how it would benefit collaborators; it would seek to engage the reward neurocircuit (Álvarez, 2012). Activities such as training, self-efficacy would also counteract the harmful effects of change.

\section{Neurosciences applied to decision making}

Up until the late 20th century, decisionmaking was thought of as a rational process 
whereby a final decision was reached, based on data and analysis, as well as an assessment of the different possible alternatives to achieve a specific objective (Rodríguez and Pinto, 2010). However, the psychologist Daniel Kahneman, winner of the 2002 Nobel Prize in economics, affirms that decisions are not rational but influenced by aspects such as intuition (Kahneman, 2002).

Advancements in new technologies applied to the study of the brain (neuroscience) have made it possible to learn the numerous existing connections between the regions of the prefrontal lobes and structures of the limbic system (where primitive neural circuits related to emotions are located), concluding that decision-making is an emotional process. Furthermore, recent studies have shown that human cognition and emotion are in constant interaction, sharing anatomical and functional brain structures, thus ruling out the existence of a rational vs. an emotional brain, as was believed for decades (Sarmiento, Ríos, and Rodríguez, 2018).

Neuroscience has attempted to understand and explain the biological mechanisms that mediate decision-making. Three elements have been proven to mediate decision-making: stress, focus, and sagacity (Caballero and Lis, 2016).

The paper published by Sarmiento and Ríos (2017) shows evidence that emotions and intuition guide decisions under mediation by brain structures such as the amygdala (related to negative emotions like stressors), which prevent the prefrontal cortex from functioning correctly. In addition, the dopaminergic neurons in the ventral tegmental area and the striatum are also affected by stress, influencing decisionmaking and affecting neurocognitive activity. Another finding is the influence of the state of mind in facing the solution to the problem: a positive state of mind led to the solution of complex problems that required discernment or creativity (Caballero and Lis, 2016).

On the other hand, the release of the hormones called catecholamines (Nogareda, 2018), as a response mechanism against stress, has encouraged studies attempting to show how the release of different substances such as dopamine and norepinephrine influence cognitive function and physiology through signaling mechanisms; this affects the loss of cognitive abilities (Rodríguez and de Rivas, 2011).

Some studies, such as the one carried out by Kawasaki, Nishimura, Takizawa, Koike, Satomura, Sakakibara, Sakurada, Yamagishi, Nishimura, Yoshikawa, Inai, Nishioka, Eriguchi, Kakiuchi, Araki, Kan, Umeda, Shimazu, Hashimoto, Kawakami, and Kasai (2015) show that there is a negative relationship between work stress and the prefrontal cortex, which hinders cognitive abilities. Likewise, Basten, Biele, Heekeren, and Fiebach (2010) affirm that investigations conducted using functional magnetic resonance imaging (FMRI) have found that the left dorsolateral prefrontal cortex and the ventral prefrontal cortex associate in comparing costs and benefits and show the difference of this comparison by neural cues of benefit anticipation produced by the amygdala and ventral striatum. This way, the brain compares cost and benefit when a person decides whether or not to accept a choice.

Among the tools brought from neuroscience to the decision-making process is eye tracking. Studies on eye movementdetermined decision-making have been used to develop effective decision-making models and describe the processes that the brain must perform while the sensory and perceptual mechanisms gather information from the outside world and the decisionmaking mechanisms select the appropriate behavior to execute an action based on that sensory information (Gutiérrez, 2019).

Other investigations have also been carried out regarding insight, a key component in decision-making. The results have yielded findings comparing the moment before decision-making and the moment when the action is executed. For example, people who analytically solved a problem showed brain activity in the area dealing with visual information (Caballero and Lis, 2016).

For the authors Ernst and Paulus (2005), the decision-making process entails three chief stages in the brain. The first is the formation of preferences. Cognitive and affective processes, like those in the neural 
circuits, coding of values, and emotional evaluation, are triggered in this stage. The second stage is the execution of the action. Here, the action is executed based on preferences, which implies choosing the highest expected reward. The last one is experiencing the result, where an assessment is made between expectations and the actual outcome from executing the action.

\section{Digital Ecosystems and Migration to Digital Transformation}

The world, through dynamic, changing markets, subject to different internal and external factors, creates an operating framework based on information and communication technologies, and it is here where the role of technology derived from applied neuroscience takes on even more importance for the study of human behavior, placing the brain as an element for observation and biometrics, such as measuring its activity (García Carrasco and Juanes Méndez, 2013).

These changing realities have led to the emergence of digital ecosystems, business ecosystems, where different actors coexist in symbiosis and contribute their skills and capabilities to the ecosystem so that it will function effectively (Chew, Derosby, Kelly, Miracky, Eggers and Muoio,2015).

These business ecosystems work under aggregate, social, or mobilization platforms (Chew, Derosby, Kelly, Miracky, Eggers, and Muoio, 2015), and it is there that using neurosciences-derived biometrics would afford more decisive information when attempting to understand and meet the needs of the client or the organization. For instance, using eye-tracking to prepare visual stimuli, heat maps, gaze positioning routes, pupillometry to measure the impact of stimulation, analyze and detect facial microexpressions to determine the emotions elicited by interaction, among other technologies capable of feeding databases for big data, machine learning, artificial intelligence and platforms in general, improving the design of its contents.

This is how the interactions between these ecosystems, on top of the individual, cultural, anthropological, social, biological experiences of each actor to them, directly modify their brain activity, a product of brain plasticity, which must be taken into account to keep the actors to the business ecosystem satisfied and permanently engaged with their contributions to the ecosystem (García Carrasco and Juanes Méndez, 2013).

Digital ecosystems, such as those that emerged in recent decades, pursue the fundamental objective to achieve a digital economy where value is created, which has been observed to be the product of engaging robust digital platforms and intelligent information management as the primary sources of value (United Nations Conference on Trade and Development, 2019)

Technological advancements have strengthened these ecosystems together with globalization and the digital migration of industries, which have led to a shift in the way work is done and how the world and markets' needs are perceived and conceived (World Bank Group, 2019) (Oppenheimer, 2018) (Ruan, Tsai, Zhang, and Zheng, 2017).

From analog to digital, these worldview changes bring about many questions, especially in the adaptation processes of companies that have retained their analogous practices rooted in the heart of the organization and its members. Such changes or modifications must stem from the organization itself through how it carries out its activities and how its members conceive and execute their work, attitudes, and, above all, the demands, requirements, and needs of its clients (Harshak, Schmaus, and Dimitrova, 2013).

The digital economy, made up of digital business ecosystems, is in direct contact with traditional administration, which must adapt through technological and scientific policies. This makes it necessary to use innovative tools that enable and enhance such digital transformation processes (Kletsova, Polozhentseva, and MoroŞan-DĂnilĂ, 2019).

Companies that are forced to shift from traditional, physical, to adapting and sustaining themselves in the digital world realm and undertake strategies centered around leadership and human resources rather than based merely on technological aspects (Kane, 2019). 
The transition to the digital economy requires transforming how administrative processes are carried out, beyond the regulation of processes and infrastructure development. This is how the administration must become aware of the impacts and added value an organization might gain if restructured around the technological information management processes (Altukhova, Vasileva, and Yemelyanov, 2018).

There are various challenges that digital transformation contexts bring along for companies; that is why it is vital to assess the potential risks of migrating from an analogous scheme to a digital one and how to deal with them and avoid the attendant effects (Khanchel, 2019). In order to face those challenges that lead the organization to be part of a digital business ecosystem, the first step is to identify critical behaviors to guide towards a multi-channel digital culture (Harshak, Schmaus, and Dimitrova, 2013).

The world has gone through several industrial revolutions, the first one in mid1776 with the appearance of steam engines, social classes, and workers' revolts. The second one with Henry Ford's contributions to mass production, electricity, and the use of various materials. The third one took place in the mid-1970s with the appearance of computer systems and the birth of the internet, and the last revolution understood as the "transformation of the world economy" into a digital economy (Martínez, 2019). The fourth industrial revolution (Industry 4.0) is the digital transformation revolution. This revolution has hit various industries, including construction and how the supply chain is managed, known as construction 4.0 (Danjou, Bled, Cousin, Roland, Perrier, Bourgault and Pellerin, 2020). Likewise, markets such as electricity have been affected by the new scenarios digital ecosystems pose, where companies almost necessarily, find themselves needing to adapt to the requirements that digital transformations bring about (Chaparro-Peláez, AcquilaNatale, Hernández-García, and IglesiasPradas, 2020)

This transformation has undergone stages that range from the use of autonomous systems, networks, services, data, information, cyberspaces to the digital age where digital identity, big-data, machine learning, the internet of things, robotics, artificial intelligence, hyper-connectivity, among other trends, make up the basis underpinning digital ecosystems and marking the migration processes towards the digital transformation (D'Antonio and de Lima Pancorbo, 2019).

Following that train of thought, the digital transformation makes ever-more trained and specialized professionals in information and communications technologies necessary for each sector of the industry and the economy, where digital ecosystems are consolidated. Likewise, all employees need to be sufficiently prepared and develop the digital skills necessary to face the changes that this new reality brings along (Huđek, Širec, and Tominc, 2019).

Changes in the ways of work and leadership are necessary to enter the digital transformation; however, it is observed that some aspects have yet to be studied in-depth, such as work-life, health, the use of information and communication technologies, performance, human resource management, and organizational hierarchies, which have proved themselves elementary in the migration towards digital ecosystems (Schwarzmüller, Brosi, Duman, and Welpe, 2018). This is where neuroscience applied to organizations gain relevance.

Multiple studies and research have been conducted on digital transformation and its implementation in some sectors in the economy such as agro-industry, finance, automotive, manufacturing, education, construction, among others (Fernández and Gutiérrez, 2019); Villarreal, García, Hernández, and Steffens, 2019; Chen, Su, Liu, and Xiang, 2020). The importance lies in the fact that incorporating new technologies into business management processes has become a competitive factor nowadays and determines an organization's strategy (Vázquez, Chivite, and Salinas, 2019). However, such an implementation has not limited itself to the economy or organizations in particular. Some investigations have gone further and proposed the digital transformation of an entire country such as Thailand and India, with government structures as the central 
axis (Sagarika, Chansukreeb, Choc, and Berman, 2018;(Verma and Dawar, 2019).

The drivers that lead an organization to engage in a digital transformation are diverse: some wish to get closer to the customer, set up strong relationships, crosssell, while others see it as an effective approach to address management issues, such as human resources, efficiency, productivity, and successful business methods design (Nadeem, Abedin, Cerpa, and Chew, 2018). Although the most common driver is usually further closeness with customers, human resource management gains relevance in the digital transformation every day, such as the proposal of Enech, Baguant, and Ivanov (2019) about a Human Resources Information System (HRIS) to support organizations' HR functions. This is a computer system used to acquire, store, manipulate, analyze, retrieve and distribute human resourcesrelated information, and its purpose is to help organizations automate most HR functions. Furthermore, HRIS has become an essential strategic tool since they collect and manage information for decision-making, which would more closely account for what is actually happening in collaborators' minds if nurtured by and coupled with neuroscience technologies.

That new business world reality requires the support of knowledge derived from neurosciences to understand the behavior of clients and the other actors to the digital ecosystems, especially concerning human resource management, leadership processes, and decision-making, where contributions to the business world are already being made.

\section{Conclusions}

The above documentary is evidence of specific contributions that neurosciences have made to administration and some of its most important dimensions, such as human resource management, leadership, and decision-making. Thus, neurosciences' tools and techniques make it possible to improve company processes, in addition to traditional techniques.

Concerning HR processes, using specialized software (Neuropsychology, Affectiva, or FACS) in selection processes can help find the ideal candidate for a job, and the job shadowing technique can ease the adaptation of new collaborators, where induction processes are concerned. Also, a reward system that enables motivation and learning will help workplace wellbeing. Those techniques could reduce high turnover rates in companies.

Regarding leadership, it is evident that successful leaders must handle their emotions, help see changes as unthreatening and exert a positive influence over their work team. With the help of technologies such as brain scans or functional magnetic resonance imaging (FMRI), it is possible to account for a leader's performance in the face of their group and review aspects to be improved in the motivational processes.

Regarding decision-making, high levels of stress were found to affect the process, as it was shown to weaken the cognitive function; thus, stress requires close monitoring. Likewise, moods, emotions, and intuition also mediate in decision making. Another aspect to bear in mind is those brain structures' functions mediating this dimension, like the left dorsolateral prefrontal cortex and the ventral prefrontal cortex, which regulate processes such as cost-benefit comparisons, a function that is common in the administrative field.

This paper has also shown how some brain functions and processes must be observed in the business environment, for they can affect human resource management, leadership, and decision-making, if unknown.

Likewise, it is established that our changing world has turned and migrated administrative environments towards the digital business ecosystems, where neurosciences can be harnessed to contribute actions and biometric practices that allow monitoring adaptation to change and help understand reactions, needs, interests, and better forms of communication with all actors to the digital ecosystems.

The variety of technologies addressed are transversal to administration and physically and through digital contexts. Throughout the theoretical and research sources that referred to them and mentioned in this paper, the following have been found: Eye tracking, Biofeedback, polygraph, GSR, EEG, 
ECG, Facial recognition of emotions, and Functional Magnetic Resonance are the most widely used.

Concerning the field of administration, it is evident that neuroscience technologies can be harnessed in any area that requires human interaction because these precisely analyze the human factor; in other words, they may be used in economics ( neuroeconomics) (Arias, 2017), leadership (neuroleadership) (Ghadiri, Habermacher, and Peters, 2012), finance (neurofinance) (Hernández, 2010) (Ramírez, 2019), personnel management (neuroselection of personnel ) (Bancayan and Dávila, 2018) (Reyes and Narváez, 2018), marketing (neuromarketing) (Álvarez, 2012), communications (neurocommunication ) (Fredericksen, 2017), I+R+D (innovation, research, and development) (neurodesign, neuro-innovation) (Puente \& Pinilla, 2018) (Soto, Ácevedo, and Labrador, 2015), and organizational management (neuromanagement) (Braidot, 2008)

\section{Conflict of interest}

The authors declare no conflict of interest.

\section{Source of Financing}

The authors declare no sources of financing.

\section{References}

Albano, S., Oviedo, R., Santero, M., Sassone, M., y Martín, S. (2016). Desarrollo de una metodología de aplicación de incentivos basada en neurociencias. Universidad Nacional del Rosario. https://www.fcecon.unr.edu.ar/webnueva/sites/default/files/u16/Decimocuartas/ albano y otros desarrollo de una metodologia 0.pdf

Albano, S., Oviedo, R., Santero, M., Sassone, M., y Martín, S. (2019). El problema de la motivación y desarrollo del capital humano en las pymes de rosario, argentina. Una propuesta basada en neurociencias. SABERES, 11(2), 171-193. https:// dialnet.unirioja.es/descarga/articulo/7205259. $\underline{p d f}$

Altukhova, N., Vasileva, E., \& Yemelyanov, V. (2018). How to Add Value to Business by Employing Digital Technologies and Transforming Management Approaches.
Business Management / Biznes Upravlenie, 1, 71-84. http://hdl.handle.net/10610/3882

Álvarez, R. (2012). Neuromarketing. Pearson.

Arias, D. (2017). Análisis de neuroeconomía como nuevo paradigma en la ciencia económica. Ciencias Económicas, 2(13), 107-119. https://doi. org/https://doi.org/10.14409/rce.v2i0.6447

Bancayan, C., y Dávila, C. (2018). Neurociencias para la gestión de los recursos humanos y comportamiento organizacional. Paideia XXI, 6(7), 129-136. https://doi.org/10.31381/paideia. v6i7.1604

Barcena, P., Cruz, K., Dávila, K., León, P., Montiel, G., y Pichardo, B. (2019). Las Neurociencias Basado en Recursos Humanos y Competencias Laborales [Trabajo para la asignatura Planeación e Integración de los Recursos Humanos]. https://es.slideshare. net/KarlaVernicaCruzJimn/neurociencias-enrecursos-humanos-y-competencias-laborales

Basten, U., Biele, G., Heekeren, H., \& Fiebach, C. (2010). How the brain integrates costs and benefits during. Psychological and cognitive sciences (PNAS), 107(50), 21767-21772. https:/l doi.org/10.1073/pnas.0908104107

Boyatzis, R., Passarelli, A., Koening, K., Mathew, B., Mathew, B., Stoller, J., \& Philips, M. (2012). Examination of the neural substrates activated in memories of experiences with resonant and dissonant leaders. The Leadership Quartely, 23(2), 259-272. https://doi.org/10.1016/j. leaqua.2011.08.003

Braidot, N. (2008). Neuromanagement: Como utilizar a pleno el cerebro en la conducción exitosa de las organizaciones. Granica.

Braidot, D. N. P. (2013). Neuromanagement y Neuroliderazgo. Cómo se aplican los avances de las neurociencias a la conducción y gestión de organizaciones. Ciencias Administrativas, (2). https://revistas.unlp.edu.ar/CADM/article/ view/706

Braidot, N. (2014). Del Management al Neuromanagement. Granica. https:/l books.google.com.co/books/about/ Neuromanagement Nueva_Edici\%C3\%B3n. html?id=NewLBAAAQBAJ\&redir esc $=\mathrm{y}$

Brain Vestigations. (2018). Neurociencia cognitiva: el motor del cambio en la gestión de los RRHH. https://www.brainvestigations.com/ neurociencia/motor-cambio-rrhh/

Caballero, L., y Lis, J. (2016). Liderazgo: una aproximación desde las neurociencias. Administración y Desarrollo, 46(1), 33-48.https:// 
dialnet.unirioja.es/descarga/articulo/6403492. pdf

Chaparro-Peláez, J., Acquila-Natale, E., Hernández-García, Á., \& Iglesias-Pradas, S. (2020). The Digital Transformation of the Retail Electricity Market in Spain. Energies, 13(8), 1-18. https://doi.org/10.3390/en13082085

Chávarro, J., y Piña, L. (2017). Neuromanagement. Una estrategia gerencial para el éxito de una organización. Formación Gerencial, (2), 190-215. https://www. researchgate.net/publication/342217946 Neuromanagement Una estrategia gerencial para el exito de una organizacion/ link/5ee9653292851ce9e7ea33f0/download

Chen, Z., Su, Y., Liu, Y., \& Xiang, Y. (2020). Application of Digital Transformation of Large Optical Microscope in Construction Engineering Management. Acta Microscopica, 29(1), 201-212. http://actamicroscopica.com/ index.php/path/article/view/355

Chew, B., Derosby, D., Kelly, E., Miracky, B., Eggers, W., \& Muoio, A. (2015). Business ecosystems come of age. Deloitte University Press. https:// www2.deloitte.com/content/dam/insights/us/ articles/platform-strategy-new-level-businesstrends/DUP 1048-Business-ecosystems-comeof-age_MASTER_FINAL.pdf

Danjou, C., Bled, A., Cousin, N., Roland, T., Perrier, N., Bourgault, M., \& Pellerin, R. (2020). Industry 4.0 in Construction Site Logistics: A Comparative Analysis of Research and Practice. Journal of Modern Project Management, 7(4), 1-15. https://www.journalmodernpm.com/index. php/jmpm/article/view/JMPM02215

D’Antonio, G., \& de Lima Pancorbo, M. (2019). Digital Securityen la nueva era de transformación digital. http://www.realinstitutoelcano.org/wps/ portal/rielcano_es/contenido?WCM_GLOBAL CONTEXT=/elcano/elcano es/zonas es/ari322019-dantonio-oliasdelimapancorbo-digitalsecurity-en-la-nueva-era-de-transformaciondigital

Daparo, N., Sánchez, F., y Serrano, R. (2015). Neurociencias en el ejercicio profesional de las Ciencias Económicas. https://bdigital.uncu.edu. ar/objetos digitales/7517/daparo-n-v-snchez-mf-serrano-r-fce.pdf

Ekman, P., y Oster, H. (1972). Expresiones faciales de la emoción. Estudios de psicología, (7), 117143. https://dialnet.unirioja.es/descarga/ articulo/65835.pdf

Elempleo. (30 de junio de 2017). La Prueba del Polígrafo: ¿en qué casos y para quiénes se usa? Elempleo. https://www.elempleo.com/ co/noticias/mundo-empresarial/la-pruebade-poligrafo-en-que-casos-y-para-quienes-seusa-5314

Ernst, M., \& Paulus, M. (2005). Neurobiology of Decision Making: A Selective Review from a Neurocognitive and Clinical Perspective. Biological Psychiatry, 58(8), 597-604. https:// www.sciencedirect.com/science/article/abs/pii/ $\underline{\text { S0006322305007109\#! }}$

Esco Universitas. (S. F.). Escuela Internacional de Neurociencia Empresarial. Obtenido de Neurociencia en los Recursos Humanos. https://www.escoeuniversitas.com/ neurociencia-en-los-recursos-humanos/

Fenech, R., Baguant, P., \& Ivanov, D. (2019). The changing role of human resource management in an era of digital transformation. Journal of Management Information and Decision Sciences, 22(2), 166-175. https://www.abacademies. org/articles/The-changing.-role-of-human.resource-management-an-era-digital-transfor mation-1532-5806-22-2-139.pdf

Fernández, V. (2015). Neurociencia (también) en el departamento de recursos humanos. https:/l revistadigital.inesem.es/gestion-empresarial/ neurociencia-tambien-en-el-departamento-derecursos-humanos/

Fernández, Y., y Gutiérrez, M. (2019). ¿Cómo percibe la banca cooperativa el impacto de la transformación digital? CIRIEC-España, Revista de Economía Pública, Social y Cooperativa, (95), 11-38. https://doi.org/10.7203/ CIRIEC-E.95.12724

Fredericksen, A. (6 de julio de 2017). Neurocomunicación; la nueva era de la comunicación política gestionada desde el cerebro. ICN. https://icndiario.com/2017/07/ neurocomunicacion-la-nueva-era-de-lacomunicacion-politica/

García Carrasco, J., y Juanes Méndez, J. A. (2013). El cerebro y las TIC. Teoría de la Educación. TESI, 14(2), 42-84. https://revistas.usal.es/ index.php/eks/article/view/10213

Ghadiri, A., Habermacher, A., \& Peters, T. (2012). Neuroleadership. Springer.

Grupo Braidot. (s.f.). Neurociencias y rrhh aplicaciones. Brain Decision. https:/l docplayer.es/11108454-Neurociencias-y-rrhhaplicaciones.html

Gutiérrez, C. (2019). Aplicaciones del eye tracking. Logos Vestigium, 59-74. https://repository. ucatolica.edu.co/bitstream/10983/23583/1/ 
registro-de-movimientos-oculares-con-el-eyetracker-mobile-eye-xg_Cap08.pdf

Harshak, A., Schmaus, B., \& Dimitrova, D. (2013). Building a digital culture How to meet the challenge of multichannel digitization. https:/l www.strategyand.pwc.com/gx/en/insights/ building-a-digital-culture.html

Hernández, M. (2010). Neurofinanzas: cuando las decisiones financieras no son racionales. TEC Empresarial, 4(3), 21-30. https://dialnet.unirioja. es/servlet/articulo?codigo $=3398008$

Huđek, I., Širec, K., \& Tominc, P. (2019). Digital Skills in Enterprises According to the European Digital Entrepreneurship Sub-Indices: CrossCountry Empirical Evidence. Management: Journal of Contemporary Management, 24(2), 107-119. https://doi.org/10.30924/mjcmi.24.2.8

Jeanneret, G., Oña, A., Rego, P., Vaiman, M., \& Pereno, G. (2015). Estudio bibliométrico de publicaciones científicas que utilizan pruebas de reconocimiento de emociones faciales. Anales de Psicología, 31(1). https://doi.org/http:// dx.doi.org/10.6018/analesps.31.1.170831

Kahneman, D. (2002). Maps of bounded rationality: a perspective on intuitive judgment and choice. Princeton University, Department of Psychology.

Kane, G. (2019). The Technology Fallacy: People Are the Real Key to Digital Transformation. Research Technology Management, 62(6), 4448. https://doi.org/10.1080/08956308.2019.166 $\underline{1079}$

Kawasaki, S., Nishimura, Y., Takizawa, R., Koike, S., Satomura, Y., Sakakibara, E., Sakurada, H., Yamagishi, M., Nishimura, F., Yoshikawa, A., Inai, A., Nishioka, M., Eriguchi, Y., Kakiuchi, C., Araki, T., Kan, C., Umeda, M., Shimazu, A., Hashimoto, H., Kawakami, N., \& Kasai, K. (2015). Using social epidemiology and neuroscience to explore the relationship between job stress and frontotemporal cortex activity among workers. Social Neuroscience, 10(3). https://doi.org/10.10 $\underline{\text { 80/17470919.2014.997370 }}$

Khanchel, H. (2019). Digital Transformation: How to Organize the Digital Function within the Tunisian Company? Review of General Management, 29(2), 145-154. http://www. managementgeneral.ro/pdf/2-2019-9.pdf

Kletsova, M., Polozhentseva, Y., \& MoroŞanDĂnilĂ, L. (2019). Evaluation of Signal Indicators of the Digital Transformation of the Russian Economy. USV Annals of Economics \& Public Administration, 19(1), 82-86. https:// ideas.repec.org/a/scm/usvaep/v19y2019i1(29) p82-86.html
Manes, F., \& Niro, M. (2015). Usar el cerebro. Paidos.

Martínez, S. (2019). La Evolución Histórica $\mathrm{De} \quad \mathrm{La}$ Transformación Digital De Las Economías Europeas. Zemsania Global Group. https://zemsaniaglobalgroup.com/ evolucion-historica-transformacion-digitaleconomias-europeas/\#: :text=La\%20 Transformaci\%C3\%B3n\%20Digital\%20de\%20 las\%20empresas\%20no\%20es\%20algo\%20innovador,con\%20holgura\%20a\%20los\%20 cambios

Mozaz Garde, M. (2009). Neurociencia einnovación. Projectics / Proyéctica / Projectique, 1(1), 19-30. https://doi.org/10.3917/proj.001.0019

Nadeem, A., Abedin, B., Cerpa, N., \& Chew, E. (2018). Digital Transformation \& Digital Business Strategy in Electronic Commerce The Role of Organizational Capabilities. Journal of Theoretical and Applied Electronic Commerce Research, 13(2). https://doi.org/10.4067/ S0718-18762018000200101

Nogareda, S. (2018). NTP 355: Fisiología del estrés. Madrid: Ministerio de Empleo y Seguridad Social, Gobierno de España. https://mobbingmadrid.org/acoso-laboral/ nota-tecnica-preventiva-355-fisiologia/

Ochsner, K. N., \& Lieberman, M. D. (2001). The emergence of social cognitive neuroscience. American Psychologist, 56(9), 717-734. https:// doi.org/10.1037/0003-066X.56.9.717

OPEM. (3 de febrero de 2021.). Neurociencias en RRHH: del conocimiento a la práctica Entrevista a Ángela Liriano, Neuropsicóloga. Orientación para el Empleo. https:/l www.orientacionparaelempleo.com/ neurociencias-en-recursos-humanos/

Oppenheimer, A. (2018). iSálvese quien pueda!: El futuro del trabajo en la era de la automatización. Penguin Random House Grupo Editorial.

Otalora, L. (2017). El neuroliderazgo y el clima organizacional en la diversidad de género. https://reunir.unir.net/bitstream/ handle/123456789/5825/OTALORA\%20 GOMEZ\%2C\%20LINA\%20MARIA. pdf?sequence $=1$ \&is Allowed $=\mathrm{y}$

Pocoví, M. (2013). Neurociencia aplicada a los recursos humanos. Emotion Research Lab. https://emotionresearchlab.com/es/blog/ neurociencia-aplicada-a-los-recursos-humanos/

Poelmans, S. (2014). El Neuroliderazgo ofrece herramientas para llegar a la eficiencia. http:/l revistas.pucp.edu.pe/index.php/strategia/ article/viewFile/18135/18379 
Puente Berdasco, D., y Pinilla Díaz, C. A. (2018). Neurodiseño: aplicación de la neurotecnología a la interpretación de las emociones que afectan la decisión de compra online en plataformas e-commerce del sector retail español. Revista EAN, 85, 181-196. https://doi. org/10.21158/01208160.n85.2018.2057

Ramírez, D. (2019). Neurofinanzas, heurística e incertidumbre en los procesos de decisión. QUADERNS IAFI, 1, 37-56. https:// revistes.ub.edu/index.php/IAFI/article/ view/31156/33385

Reyes, G., y Narváez, E. (2018). Neurociencia como herramienta para la gestión del talento humano. Universidad Nacional Autónoma de Nicaragua. http://repositorio.unan.edu.ni/8583/1/18829. pdf

Rodríguez, R., y de Rivas, S. (2011). Los procesos de estrés laboral y desgaste profesional (burnout): diferenciación, actualización y líneas de intervención. Medicina y Seguridad del Trabajo, 57(1), 72-88. https://dx.doi.org/10.4321/ S0465-546X2011000500006

Rodríguez, Y., y Pinto, M. (2010). Evolución, particularidades y carácter informacional de la toma de decisiones organizacionales. ACIMED, 21(1). http://scielo.sld.cu/scielo.php?script=sci arttext\&pid=S1024-94352010000100006

Ruan, F., Tsai, R., Zhang, K., \& Zheng, T. (2017). A Study of Employment and Talent in the Digital Economy (Part I). https://image-src.bcg.com/ Images/BCG Year-2035 400-Million-JobOpportunities-Digital\%20Age ENG Mar2017 tcm52-153963.pdf

Sagarika, D., Chansukreeb, P., Choc, W., \& Berman, E. (2018). E-government 4.0 in Thailand: The role of central agencies. Information Polity, 343-353. https://doi.org/10.3233/IP-180006

Salas, C. (2013). La neurociencia en las organizaciones empresariales. PMFARMA.

Salazar, D. (2019). Importancia de la poligrafía en un proceso de selección de personal preempleo [Trabajos de Grado, Universidad Militar Nueva Granada]. https://repository.unimilitar. edu.co/bitstream/handle/10654/35693/

SalazarLatorreDerlingElibeth2019. pdf?sequence $=1$

Sarmiento, L., y Ríos, J. (2017). Bases neurales de la toma de decisiones e implicación de las emociones en el proceso. Revista Chilena de Neuropsicología, 12(2), 32-37. https://www. redalyc.org/pdf/1793/179354005006.pdf

Sarmiento, L., Ríos, J., y Rodríguez, V. (2018). La Toma de Decisiones en el Cerebro: una
Perspectiva Emocional. Editorial el manual moderno. https://www.researchgate.net/ publication/323497336 La Toma de

Decisiones_en_el_Cerebro_una_Perspectiva Emocional

Schultz, W. (2015). Neuronal Reward and Decision Signals: From Theories to Data. Physiological reviews, 95(3), 835-951. https://doi.org/10.1152/ physrev.00023.2014

Schwarzmüller, T., Brosi, P., Duman, D., \& Welpe, I. M. (2018). How Does the Digital Transformation Affect Organizations? Key Themes of Change in Work Design and Leadership. Management Revue, 29(2), 114-138. https://doi.org/10.5771/0935-9915-2018-2-114

Sesametime. (S.F.). La Neurociencia y los Recursos Humanos. https://superrhheroes. sesametime.com/la-neurociencia-los-recursoshumanos/\#: :text=La\%20neurociencia\%20 se $\% 20$ entiende $\% 20$ como,el $\% 20$ desempe $\%$ C3\%B10\%20de $\% 2010$ \% $\% 20$ empleados

Soto, M., Ácevedo, Á., y Labrador, L. (2015). La Neuroinnovación del Ser característica potenciadora del emprendimiento social. Cultura, Educación y Sociedad, 6(2), 5162. $\quad$ https://revistascientificas.cuc.edu.co/ culturaeducacionysociedad/article/view/842/ pdf 107

Tetaz, M. (22 de junio de 2015). Neuroanatomía de la decisión. https://www.martintetaz.com/ neuroanatomia-de-la-decision/

United Nations Conference on Trade and Development. (2019). Digital Economy Report: Value Creation and Capture: Implications for Developing Countries. United Nations.

Vallejo, D., Abarca, R., Uquillas, G., y Ramirez, R. (2017).Inteligencia emocionalyelneuroliderazgo en las empresas públicas. Revista Observatorio de la Economía Latinoamericana. http:// www.eumed.net/cursecon/ecolat/ec/2017/ inteligencia-emocional-empresas.html

Vázquez, J., Chivite, M., y Salinas, F. (2019). La transformación digital en el sector cooperativo agroalimentario español: situación y perspectivas. CIRIEC-España, Revista de Economía Pública, Social y Cooperativa, 95, 3970. https://doi.org/10.7203/CIRIEC-E.95.13002

Verma, N., \& Dawar, S. (2019). Digital Transformation in the Indian Government. Communications of the ACM, 62(11). https://doi. org/https://dl.acm.org/doi/10.1145/3349629

Villarreal, S., García, J., Hernández, H., y Steffens, E. (2019). Competencias Docentes 
y Transformaciones en la Educación en la Era Digital. Formación Universitaria, 12(6). http:// dx.doi.org/10.4067/S0718-50062019000600003

Waldman, D., Balthazard, P., \& Peterson, S. (2011). Social cognitive neuroscience and leadership.
The Leadership Quarterly, 22(6). https:// www.sciencedirect.com/science/article/pii/ $\underline{\text { S1048984311001524 }}$

World Bank Group. (2019). The Changing Nature of Work. http://documents.worldbank.org/ curated/en/816281518818814423/2019-WDRReport.pdf

How to cite this paper?

Varón Sandoval, A., \& Zapata Castillo, L. C. (2021). A theoretical approach to neuroscience technologies' contributions to administration in the digital transformation context. Cuadernos de Administración, 37(69), e4010691. https://doi.org/10.25100/cdea.v37i69.10691 